Artikel Penelitian

\title{
Efek Pencabutan Gigi terhadap Peningkatan Tekanan Darah pada Pasien Hipertensi
}

\author{
Kartika Mega Rahman ${ }^{1}$, Darwin Amir $^{2}$, Mustafa Noer ${ }^{3}$
}

\begin{abstract}
Abstrak
Pencabutan gigi merupakan tindakan mengeluarkan gigi dari soket tulang alveolar. Tindakan pencabutan yang menimbulkan perlukaan, maka dapat timbul efek seperti perdarahan. Faktor resiko yang sering kali menjadi komplikasi terjadinya perdarahan adalah tingginya tekanan darah pada pasien yang dilakukan pencabutan gigi. Tujuan penelitian ini adalah menentukan efek pencabutan gigi terhadap peningkatan tekanan darah pada pasien hipertensi. Penelitian dilakukan dari 15 September hingga 6 Oktober 2014 dengan hasil penelitian didapatkan 15 responden hipertensi dan 15 responden normotensi. Penelitian ini menggunakan rancangan cross sectional comparative dengan sampel yang direkrut menggunakan metode consecutive sampling. Data didapatkan dari pengukuran tekanan darah sebelum dan setelah tindakan pencabutan gigi yang kemudian dianalisis menggunakan $t$-test dengan tingkat kepercayaan 99\%. Hasil penelitian menunjukkan adanya perbedaan nilai tekanan darah awal antara kelompok hipertensi dengan normotensi sebelum pencabutan gigi $(p<0,01)$. Setelah tindakan pencabutan gigi pada 15 subjek hipertensi $(100 \%)$ dan 15 subjek normotensi $(100 \%)$ juga terdapat perbedaan nilai tekanan darah akhir $(p<0,01)$. Peningkatan tekanan darah hanya terjadi pada 15 subjek hipertensi (100\%) dimana peningkatan terdapat pada tekanan darah darah sistolik yaitu sebesar $12 \pm 3,7 \mathrm{mmHg}(p<0,01)$. Berdasarkan hasil penelitian disimpulkan bahwa terdapat peningkatan tekanan darah sistolik pada pasien hipertensi yang dilakukan tindakan pencabutan gigi.
\end{abstract}

Kata kunci: pencabutan gigi, tekanan darah, hipertensi

\section{Abstract}

Tooth extraction is the act of removing a tooth from the alveolar bone. Bleeding may arise from the injury of tooth extraction. Risk factors that often causes a complication of hemorrhage is high blood pressure in patients who under tooth extraction. The objective of the study was to determine the effect of tooth extraction on the increasing blood pressure in hypertensive patients. The study was held on September 15 until October 6 with the result of the study obtained 15 hypertensive respondents and 15 respondents with normal blood pressure. The design of the study was cross sectional comparative with the sample that taken with consecutive sampling method. The results was analyzed with student $t$ - test that had 99\% level of confidence. The results showed that there's a difference in blood pressure between hypertensive subjects and normal blood pressure subjects before tooth extraction $(p<0,01)$. After tooth extraction in 15 hypertensive subjects (100\%) and 15 normal blood pressure subjects there's also difference in blood pressure $(p<0,01)$. Increasing in blood pressured only occurs in 15 hypertensive subjects $(100 \%)$ which there's increase in systolic blood pressure that is equal to $12 \pm 3,7 \mathrm{mmHg}(p<0,01)$. It can be concluded that there's increase in systolic blood pressure in hypertensive subjects after tooth extraction.

Keywords: tooth extraction, blood pressure, hypertension

Affiliasi penulis: 1, Prodi Profesi Dokter FK Unand (Fakultas Kedokteran Universitas Andalas Padang), 2. Bagian IImu Saraf FK Unand, 3. Bagian IImu Gigi dan Mulut FK Unand Korespondensi: Kartikia Mega Rahman, Email: kartikamegarahman@yahoo.com, Telp: 081993328171

\section{PENDAHULUAN}

Tindakan pencabutan gigi merupakan suatu tindakan yang sehari-hari dilakukan oleh dokter gigi yang tidak jarang ditemukan komplikasi dari tindakan pencabutan gigi. Oleh karena itu perlu waspada dan mampu mengatasi kemungkinan komplikasi yang dapat terjadi. ${ }^{1}$

Tidak semua pasien yang dilakukan pencabutan gigi datang dalam keadaan sehat dan memiliki tekanan darah yang normal. Ada yang datang 
dalam keadaan tekanan darah normal dan ada juga yang datang dalam keadaan hipertensi. Kondisi tekanan darah pasien yang berbeda memerlukan pengelolaan yang tidak sama, sehingga pencabutan gigi hanya dapat dilakukan jika keadaan lokal maupun keadaan umum penderita yaitu status fisik dalam keadaan yang sehat. Kemungkinan terjadinya komplikasi setelah pencabutan dapat terjadi walaupun hanya pada satu gigi adalah peningkatan tekanan darah pada penderita hipertensi yang dilakukan pencabutan gigi. ${ }^{1}$

Tekanan darah adalah daya dorong ke semua arah pada seluruh permukaan yang tertutup pada dinding bagian dalam jantung dan pembuluh darah. Tekanan darah adalah tekanan yang dihasilkan oleh darah terhadap pembuluh darah. Tekanan darah dipengaruhi curah jantung dan elastisitas pembuluh darah. Peningkatan tekanan darah disebabkan oleh peningkatan volume darah atau elastisitas pembuluh darah. Sebaliknya, penurunan volume darah akan menurunkan tekanan darah. ${ }^{2}$

Hipertensi adalah gangguan pada pembuluh darah yang mengakibatkan suplai oksigen dan nutrisi yang dibawa oleh darah terhambat sampai ke jaringan yang membutuhkan. Hipertensi sering kali disebut sebagai pembunuh gelap, karena termasuk penyakit yang mematikan tanpa disertai dengan gejalagejalanya lebih dahulu sebagai peringatan bagi penderitanya. $^{3}$

Respon tekanan darah selama perawatan gigi dipengaruhi oleh berbagai faktor. Ketika pasien dalam kondisi sadar selama perawatan gigi, terdapat peningkatan tekanan darah yang dikaitkan dengan rasa cemas atau stres fisiologis, termasuk stimulus rasa nyeri dan efek dari vasokonstriktor yang terdapat dalam anestesi yang diberikan. Peningkatan tekanan darah lebih terlihat pada pasien hipertensi dibandingkan dengan pasien dengan normotensi. ${ }^{4}$

\section{METODE}

Penelitian ini dilakukan selama dua minggu dalam bulan September 2014 di Poli Gigi RSUP Dr. M. Djamil, RS Tentara Dr. Reksodiwiryo dengan desain cross sectional comparative. Populasi dari penelitian ini adalah seluruh pasien Poli Gigi RSUP Dr. M. Djamil Padang, RS Tentara Dr. Reksodiwiryo yang memenuhi kriteria inklusi berupa pasien yang akan dilakukan tindakan pencabutan gigi dengan tekanan darah normal dan hipertensi terkontrol atau tingkat satu dan tidak memenuhi kriteria eksklusi berupa pasien dengan diabetes, pasien hipertensi yang mengonsumsi obat anti hipertensi dan pasien dengan usia di bawah 12 tahun. Penelitian ini membandingkan kelompok pasien hipertensi yang akan dilakukan ekstraksi dengan kelompok tekanan darah normal yang akan dilakukan ekstraksi. Pada masing masing akan diperiksa tekanan darahnya disaat sebelum tindakan ekstraksi dan setelah ekstraksi berakhir.

Metode pengambilan sampel pada penelitian ini adalah total sampling. Variabel independen pada penelitian ini adalah ekstraksi gigi dan variable dependennya adalah tekanan darah. Analisis data pada penelitian ini dilakukan dengan analisis bivariat untuk mencari hubungan antara dua variable dengan menggunakan rumus t-test.

HASIL

Karakteristik Subjek

Tabel 1. Karakteristik subjek berdasarkan jenis, umur dan tekanan darah

\begin{tabular}{llll}
\hline & Jumlah & $\%$ & Jumlah \\
\hline $\begin{array}{l}\text { Jenis Kelamin } \\
\quad \text { Perempuan }\end{array}$ & 9 & 30 & $100 \%$ \\
$\quad$ Laki-laki & 21 & 70 & \\
Umur & & & \\
Remaja & & & \\
Dewasa & & 13,33 & $100 \%$ \\
Lansia & 6 & 20 & \\
$\begin{array}{l}\text { Tekanan Darah Awal } \\
\text { Normotensi (100-139 / }\end{array}$ & 15 & 50,6 & \\
$\begin{array}{l}70-80 \text { mmHg) } \\
\text { Hipertensi (140-159 / } \\
60-90 \text { mmHg) }\end{array}$ & 15 & 50 & \\
$\begin{array}{l}\text { Tekanan Darah Akhir } \\
\text { Normotensi (100-139 / }\end{array}$ & 15 & 50 & \\
$70-80$ mmHg) \\
$\begin{array}{l}\text { Hipertensi (150-169 / } \\
60-90 \text { mmHg) }\end{array}$ & 15 & 50 & \\
\hline
\end{tabular}

Usia termuda subjek pencabutan gigi yang terdapat dalam kriteria inklusi adalah 18 tahun dan usia tertua adalah 74 tahun. Frekuensi terbanyak terdapat pada kelompok jenis kelamin laki - laki dengan jumlah 21 subjek yaitu sebanyak $70 \%$ dengan frekuensi pencabutan gigi tertinggi terdapat 
dalam kelompok umur 51 - 60 tahun sebanyak 11 subjek.

Nilai tekanan darah dasar yang didapatkan dari kelompok normotensi adalah 100-109/70 - 80 mmHg sebanyak 2 subjek, $110-119 / 70-80 \mathrm{mmHg}$ sebanyak 6 subjek, 120 - 129/ $70-80$ mmHg sebanyak 4 subjek dan 130 - 139/ 70 - 80 sebanyak 3 subjek. Sementara untuk tekanan darah dasar kelompok hipertensi adalah 140-149 / 60-70 mmHg sebanyak 1 subjek, 140-149 / 80-90 mmHg sebanyak 13 subjek dan 150-159/ 80-90 mmHg sebanyak 1 subjek.

\section{Hasil pengukuran}

Tabel 2. Tekanan darah subjek hipertensi dan normotensi sebelum tindakan pencabutan gigi

\begin{tabular}{lrlll}
\multicolumn{1}{c}{ TD } & \multicolumn{3}{c}{ Rerata \pm SD $(\mathbf{m m H g})$} & \\
\cline { 2 - 4 }$(\mathbf{m m H g})$ & $\mathbf{n}$ & hipertensi & normotensi & $\mathbf{P}$ \\
Sistolik & 15 & $141.33 \pm 3$ & $115.33 \pm 9$ & $<0,01$ \\
Diastolik & 15 & $85.33 \pm 8.3$ & $77.33 \pm 4.5$ & $>0,01$ \\
\hline
\end{tabular}

Terdapat perbedaan nilai tekanan darah sistolik yang signifikan antara kelompok hipertensi dengan normotensi sesaat sebelum dilakukannya tindakan pencabutan gigi dan pada diastolik tidak terdapat adanya perbedaan yang signifikan antara kedua kelompok tersebut. Nilai rerata tekanan darah sistolik pada 15 subjek hipertensi adalah $141 \pm 3 \mathrm{mmHg}$ dan diastolik $85 \pm 8,3 \mathrm{mmHg}$, sementara untuk rerata tekanan darah sistolik pada 15 subjek normotensi adalah $115 \pm 9 \mathrm{mmHg}$ dan diastolik $77 \pm 4,5 \mathrm{mmHg}$ Nilai yang dihasilkan menggunakan rumus uji t pada tekanan darah sistolik adalah $(p<0.01)$ dimana nilai tersebut memiliki arti signifikan atau terdapat adanya perbedaan.

Tabel 3. Tekanan darah pasien hipertensi dan normotensi setelah tindakan pencabutan gigi

\begin{tabular}{lrlll}
\hline TD & \multicolumn{3}{c}{ Rerata \pm SD $(\mathbf{m m H g})$} & \\
\cline { 2 - 4 }$(\mathbf{m m H g})$ & $\mathbf{n}$ & hipertensi & normotensi & $\mathbf{P}$ \\
\hline Sistolik & 15 & $153.33 \pm 4$ & $115.33 \pm 9$ & $<0,01$ \\
\hline Diastolik & 15 & $85.33 \pm 8.3$ & $77.33 \pm 4.5$ & $>0,01$ \\
\hline
\end{tabular}

Rerata tekanan darah sistolik sebelum dilakukan pencabutan gigi pada kelompok hipertensi sebesar $141,33 \pm 2.9 \mathrm{mmHg}$ dan rerata setelah pencabutan gigi sebesar 153,33 $\pm 4.0 \mathrm{mmHg}$ sehingga didapatkan peningkatan tekanan darah sistolik sebesar $12 \pm 3,6 \mathrm{mmHg}(p<0,01)$, sedangkan nilai rerata tekanan darah diastolik pada kelompok hipertensi tidak mengalami perubahan sebelum ataupun setelah pencabutan gigi.

\section{PEMBAHASAN}

Pada penelitian ini terlihat bahwa subjek hipertensi yang dilakukan tindakan pencabutan gigi mengalami peningkatan pada tekanan darah sistolik. Hal ini sejalan dengan pernyataan Tsuchihashi et al (1996) yang mengatakan bahwa terdapat peningkatan tekanan darah pada pasien hipertensi yang dilakukan tindakan pencabutan gigi. Faktor yang menyebabkan peningkatan tekanan darah adalah stress psikologi dan fisik, stimulasi nyeri dan penggunaan anestesi yang mengandung vasokonstriktor. Peningkatan tekanan darah yang disebabkan oleh stres mental mengalami peningkatan yang minimal dan tidak signifikan saat pemeriksaan stres mental, sehingga terdapat dua faktor yang lebih mempengaruhi peningkatan tekanan darah yaitu penggunaan anestesi dan tindakan pencabutan gigi. ${ }^{4,6}$

Faktor lain yang menyebabkan peningkatkan tekanan darah pada pasien hipertensi adalah kerentanan jantung dan pembuluh darah dimana telah terdapat berbagai resiko awal yang meningkatkan tekanan darah dari batas normal. Seseorang yang memiliki riwayat hipertensi menyebabkan peningkatan tekanan darah yang lebih tinggi dibanding dengan seseorang tanpa riwayat hipertensi, hal ini disebabkan oleh hiperaktifnya saraf simpatis yang menyebabkan timbulnya respon yang berlebih pada penderita hipertensi, terlebih jika didukung dengan riwayat hipertensi dalam keluarga.,

\section{SIMPULAN}

Terdapat efek yang bermakna dari pencabutan gigi terhadap peningkatan tekanan darah sistolik pada pasien hipertensi.

\section{DAFTAR PUSTAKA}

1. Gunawan L. Hipertensi tekanan darah tinggi. Yogyakarta: Kanisius; 2001.hlm.7-8.

2. Sloane E.. Anatomi dan fisiologi untuk pemula. Veldman J (penterjemah). Jakarta: EGC; 2004. hIm. $238-9$. 
3. Sustrani L.. Hipertensi. Jakarta: Gramedia Pustaka Utama; 2004.hlm. 8.

4. Tsusuchihashi T, Takata $Y$, Kurokawa H, Miura K, Maruoka Y, Kajiyama M Fujishima M. Blood pressure repsons during dental surgery. Japan: Kyushu University; 1996. hlm. 189-91.

5. Gupta K, Gupta N. A Comparative study of cardiovascular response in hypertensive and normotensive parents. International Journal of Basic and Applied Medical Sciences. 2014:187-91.
5. Bader JD, Bonito AJ, Shugar DA. Cardiovascular effects of epinephrine in hypertensive dental patients. United States. Agency for Healthcare and Quality (US);2002. hlm. 291.

6. Miura K, Matsumura K, Nakamura Y, Kurokawa H, Kajiyama M, Takata Y. Suppression of cardiac sympathetic nervous system during dental surgery in hypertensive patients. Japan. Departmen of Oral and Maxillofacial Surgery; 2000. hlm. 207 - 8. 